\title{
Cervical Lymph Node
}

National Cancer Institute

\section{Source}

National Cancer Institute. Cervical Lymph Node. NCI Thesaurus. Code C32298.

Any of the lymph nodes located in the neck. 